\title{
EFFECT OF FLASH SALE METHOD, PRODUCT KNOWLEDGE AND IN HOME SHOPPING TENDENCY TOWARD CONSUMER ONLINE PURCHASE DECISIONS
}

\author{
Aribowo Doddy Hertanto, Sulhaini, Herman Lalu Edi \\ Faculty of Economics and Business, University of Mataram, Indonesia \\ *E-mail: doddyhert@gmail.com
}

\begin{abstract}
This research aims to determine the influence of variable flash sale, product knowledge and in home shopping tendency to purchase decision. Samples were taken with purposive random sampling method who came from online store consumers in Indonesia. Analysis done by Moderated Regression Analysis (MRA) is to know the effect of flash sale (independent variables) on purchasing decisions (dependent variables) with product knowledge and in home shopping tendency as moderation variables. The results showed that there were positive influence and significant flash sale on purchasing decision, as well as the positive and significant moderation effect of product knowledge and in home shopping tendency towards flash sale relationship and purchase decision.
\end{abstract}

\section{KEY WORDS}

Flash sale, purchase decision, product knowledge, in home shopping tendency, online store.

The rapid development of information technology in Indonesia is very influential in the changes in the field of marketing activities. Report of survey results from wearesocial.com, until the beginning of 2020 there are 175.4 million Internet users in Indonesia or $64 \%$ of the population of Indonesia. Internet utilization in Indonesia not only to communicate but also to do online buying and selling activities. The wearesocial.com report states that Indonesia is the country with the biggest online store in the world beating Thailand and Poland, where it has reached $88 \%$ of all Internet users in Indonesia. Various ways of online sales include utilizing social media, through marketplace, e-commerce and websites specifically for product sales. According to data collected by CNN quoted from CupoNation, in Indonesia until the end of 2019 known Tokopedia is the most visited online store by Indonesian Internet users with a total of 1.2 billion visitors. In the second order is the online shopping site Shopee followed by Bukalapak, Lazada, Blibli, JD.ID, Orami, Bhinneka, Sociolla and Zalora. An interesting strategy was applied by Shopee which is a promo done at the end of the year with the theme Harbolnas 11:11 and 12:12 that offers flash sale and other promo. Other than Shopee online shop such as Tokopedia, Bukalapak, Lazada and Blibli also apply flash sale strategy.

In this research the authors will focus on the online sales methods that are widely used today namely flash sale. Flash sale is a product sale online by offering an attractive price (discounts) that are quite large but with a limited number of products and time periods of sale. Flash sale was first introduced by French e-commerce named Veepee at the end of the year 2000, the current CEO Jacques-Antoine Granjon and his colleagues created a limited sales concept on the Internet, the principle is to fulfill the wishes of suppliers who want to quickly sell excess inventory without damaging the brand image or competing with other distribution channels. Veepe at the time sold the product at a discounted price of $50 \%$ up to $70 \%$.

In an effort to fulfill the needs of consumers will make purchases both in conventional stores and through online stores through the stage of the purchasing decision process. According to Kotler \& Amstrong (2012:226), the purchasing decision is a stage in the decision-making process by buyers where consumers actually buy. Purchasing decisions influenced by factors of internal factors derived from consumer self consist of consumer perception, work, lifestyle, personality and Confidence (Kotler 2008:45) as well as external factors that exist outside the individual consumers who are a referral group, social, cultural 
and family class (Schiffman \& Kanuk, 2008:71), as well as external factors derived from the marketing efforts undertaken by the Company and information from the consumer environment that includes products, price, service, location, promotion.

Sujata, Menachem, Akshay \& Viraj (2017) in the study stated that flash sale helps increase revenue for ecommerce companies, in addition to that discount strategy leads to more products that can be sold, where discounts are the main reasons why consumers buy online or offline. Vannisa, Fansuri \& Ambon (2020) in his research found that there are significant positive effects of flash sale selling methods against online shopping enjoyment and online impulse buying.

In Kannan's study, Babu, Hu, \& Narasimhan (2014) stated that the seller used social media and flash sale methods to promote and sell their new product where the sales method with flash sale turned out to increase visitors to the main website and increase daily sales for all products sold on the site. Zhang, Zhang J., Cheng, \& Hua (2018) in his research stating the platform or sales site with the flash sale method has two functions, namely promoting the product and increasing the demand in the sales period, and become a profit channel for the seller. Research topic flash sale also done by Aday (2013) which found that the frequency of purchase through online, positive attitude (acceptance) of consumers, and product awareness directly affects the motivation to purchase against vouchers sold by means of flash sale.

In research Aday (2013) states that there has not been any academically published research on the concept of flash sale. More credible information is obtained from news sites on the Internet. Research on flash sale method is still a little done, from articles that have been published research conducted in the region of America, Europe and India where the object is focused on the site of the provider of flash sale originating from these countries. From the research that has been done has not done research that includes variables that can moderate flash sale so it affects the purchase decision. The author proposed a new empirical model in this study by including two variables that influenced the purchasing decision by the flash sale method of product knowledge and In Home shopping tendency variables. Product knowledge that is owned by consumers has different levels because of the difference in the ability to receive information on products sold which will affect the purchasing decision. In the condition of selling the consumer flash sale method only has a limited time to immediately decide buy with various considerations based on his knowledge. Another moderation variable is the ease of shopping from home (in home shopping tendency), currently to conduct shopping transactions, consumers are just enough to capital Internet connection either through a computer desktop or a smartphone. The in home shopping tendency variable is the dimension of shopping oriented is the tendency for people to make purchases without leaving home is done with shopping in the online store.

Based on the discussion presented above, the author will conduct research on the influence of flash sale toward purchase decision that is moderated by the variable product knowledge and in home shopping tendency.

\section{LITERATURE REVIEW}

According to Zhang et al (2016) the flash sale is a popular e-commerce marketing mode in which branders sell a number of new products at discounted prices within a specified time before the normal sales period. Aday (2013) defines a flash sale is a voucher purchased online from sites like Groupon or LivingSocial and can be used on certain future businesses/products. Flash sale is a product sale either online or offline by offering a price, which is attractive (discounts) with a limited number of products and time periods of sale.

The purpose of selling with flash sale for sellers is to increase transactions on ecommerce, stimulate product sales, increase brand awareness on certain brands to increase sales. It is also a tool to determine the number of requests for a particular product and to reach more consumers. 
According to Kotler \& Keller (2007:235-243) in the decision making of the purchase of an item by the consumer will be through the decision making process divided into the following five stages:

- Introduction of need/want recognition;

- Information research;

- Alternative evaluation;

- Purchase decision or not;

- Post-purchase behaviour.

The decision of purchase according to Kotler (2002) is the act of the consumer to want to buy or not to the product. follows:

According to Swastha \& Irawan (2012) The Purchase Decision has six dimensions as

- Product type decisions, namely the condition in deciding to buy a product type from different options;

- Brand decisions, which are conditions when consumers decide which brands to buy;

- Seller's decision, which is the situation when consumers choose the seller;

- Decision on the number of products, related to the number of products purchased;

- Purchase time decision, which is the situation when consumers choose the right time to make a purchase;

- Decision on how to pay, namely the situation when the consumer chooses the payment method to suit the wishes.

Based on the above definition, it is concluded that the buying decision is the action that consumers take to purchase a product.

Consumer knowledge of products will be crucial to determining purchasing decisions. According to Peter \& Olson (2010:70-75), there are four indicators of product knowledge:

- The attributes or characteristics of the product are all physical and non-physical aspects of a product or service that can be seen or felt. There are two attributes that are tangible attributes of physical characteristics and abstract attributes are subjective characteristics that cannot be touched;

- The physical benefit is a direct impact can be felt on the consumer's prayer using products or services;

- Psychological benefits are the social impact that consumers obtain when using a product or service;

- Consumer value-rate can be explained that human beings have knowledge of personal and symbolic value that can be fulfilled or satisfied by a product purchased. When the value has been satisfied or the main purpose of life is achieved is likely to be unreal and subjective.

According to Lin \& Chen (2006) there are three dimensional consumer products knowledge as follows:

- Consumer perception is the perception of excellence and how to use the product appropriately;

- Memory which is the product specifications contained in the consumer's memory of the product type;

- Consumer experience is the experience when using the product.

In home shopping tendency is a dimension of shopping orientation, based on people who are shopping divided into two namely in home shopping and shopping mall (Darden and Reynolds 1971; Hawes and Lumpkin 1984). Vijayasarathy \& Jones (2000) presents a sevenfactor or shopping orientation that is an in home shopper (likes shopping from home), economical shopper (survey before making a purchase), mall shopper (prefers shopping at the mall), personalized Shopper (shopping where he knows the salespeople), ethical shopper (likes shopping at local stores), convenience shopper (wants comfort at the time of shopping) and enthusiastic shopper (enjoy shopping activities).

Meanwhile, Seock in Kusuma \& Septarini (2013) presents seven dimensions of shopping orientation namely shopping enjoyment, brand/fashion consciousness, price 
consciousness, shopping confidence, convenience/time consciousness, brand/store loyalty and in home shopping tendency. As for the notion of dimension in home shopping tendency is an individual tendency to make purchases or shopping by not going out of the house.

Flash sale is one of the sales methods done by giving discounts on products sold where the number of products is limited to a certain amount and sales within a predetermined period of time. The goal of flash sale, among others, increases sales, with the stimulus being expected to influence purchasing decisions from consumers. In research Sujata, Menachem, Akshay \& Viraj (2017), explains that the flash sale done by the Flipkart site, Amazon and Snapdeal shows that this method increases the company's revenue is demonstrated by the high number of sales, as well as in the research of Kannan, Babu, Hu, \& Narasimhan (2014) states the method of selling with flash sale turns increasing visitors to the main website and can increase sales. The description is proposed by the following hypothesis:

H1: The influence of flash sale toward purchase decisions.

In research that has been done states that the quality of information is a factor that most influence buying decisions through e-commerce (Yuniarty \& Abbas 2018). Research Ercis \& Bilal (2018) expressed consumer knowledge as a variable moderating the relationship value perceptions of purchase intention where it is found that consumer knowledge has the effect of moderation of personal value perceptions and the purchase intent of luxury goods also the relationship between functional value perceptions and the intention of purchasing luxury goods.

Research conducted Mahmoud, T.O., Ibrahim, S. B., \& Hasaballah, A. H. A. (2017) environmental knowledge as a variable of moderation of relationships between green marketing mix (product, price, place promotion) with the intention of buying (purchase intention). Product knowledge that is the knowledge of consumers of a product includes knowledge of specifications, features, usability and benefits when using the product. In the process of deciding to buy a particular product a prospective consumer will involve the ability to assess a product with its knowledge in which the process takes place before deciding on a purchase. Research Pucci, T., Casprini, E., Nosi, C., \& Zanni, L. (2018) expressed the relationship that knowledge (subjective \& objective) provides a moderation effect on the social media use and purchase of wine products sold online.

In the flash sale method sale in online store where the products sold can only be seen by digital and limited time of sale then in the process of making a purchase will be strongly influenced by the ability of a person to know the specifications, quality and benefits of the products sold, in which case it will affect or weaken someone to decide to buy. From the description, the knowledge of products or product knowledge is submitted as the second hypothesis as follows:

H2: Product knowledge moderates the influence of flash sale toward purchase decisions.

The convenience of consumers to shop from home or can shop from anywhere to be one of the consumer options is through online shopping. Today the tendency to shop online is increasing along with the development of technology and the emergence of various methods of marketing products. In his research Seock \& Bailey (2008) found that in home shopping tendency (the trend of home spending) was positively related to online information search about products and online purchases. Research Alturas (2004) reveals a positive correlation between home shopping and consumer satisfaction. The tendency of people to go shopping from home (in home shopping tendency) is chosen or done because of the online shopping system.

In the research Balabanis, G. \& Vassileiou, S. (1999) One of them stated that consumer experience doing home shopping activity had a positive effect on the respondent's intention to purchase from the online seller's website. Online sales method varies one of them is done by flash sale method, in the process of deciding to buy goods when flash sale then the attitude of people who tend to prefer shopping from home (in home shopping tendency) will affect the relationship both strengthening and weakening when consumers will decide to buy the goods. The third hypothesis was proposed: 
H3: In home shopping tendency to moderate the influence of flash sale toward purchase decisions.

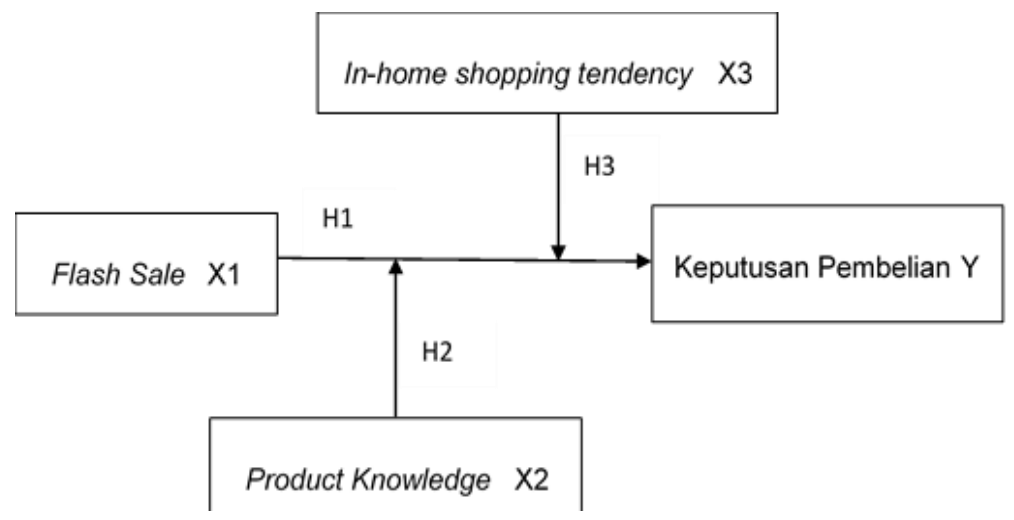

Figure 1 - Conceptual Framework I

\section{METHODS OF RESEARCH}

The study used a quantitative approach of research by conducting hypothesis testing, measuring variables using numbers, and analyzing data using statistical calculations. This research examines the influence of a variable to other variables or knows the relationship between variables is a type of associative research-causality.

This research was conducted by spreading online questionnaire to 200 respondents with criteria aged $\geq 18$ years and using the online store in the previous 6 months. As of table 1 it is known that the majority of respondents were between 18-28 years old where they were average students with a majority income of $\leq 2$ million. If viewed from the distribution of respondents, it covers all the major islands in Indonesia with a large percentage on the island of Java and Bali \& Nusa Tenggara.

Table 1 - Characteristic of Respondents

\begin{tabular}{|c|c|c|c|}
\hline Respondents Profile & Frequency & \multicolumn{2}{|c|}{ Percentage } \\
\hline \multirow[t]{2}{*}{ Gender } & Male & 102 & $51 \%$ \\
\hline & Female & 98 & $49 \%$ \\
\hline \multirow[t]{3}{*}{ Age } & $18-28$ years & 138 & $69 \%$ \\
\hline & $29-39$ years & 47 & $23,5 \%$ \\
\hline & $40-50$ years & 15 & $7,5 \%$ \\
\hline \multirow[t]{3}{*}{ Education } & $\leq$ Senior High School & 154 & $77 \%$ \\
\hline & D3 & 5 & $2,5 \%$ \\
\hline & S1 & 41 & $20,5 \%$ \\
\hline \multirow[t]{5}{*}{ Occupation } & Students & 120 & $60 \%$ \\
\hline & Private Employees & 31 & $15,5 \%$ \\
\hline & Government Employees & 2 & $1 \%$ \\
\hline & Entrepreneur & 30 & $15 \%$ \\
\hline & Others & 17 & $8,5 \%$ \\
\hline \multirow[t]{3}{*}{ Income } & $\leq 2$ million & 141 & $70,5 \%$ \\
\hline & $2-5$ million & 55 & $27,5 \%$ \\
\hline & $5-10$ million & 4 & $2 \%$ \\
\hline \multirow[t]{6}{*}{ Island Stay } & Java & 76 & $38 \%$ \\
\hline & Sumatra & 13 & $6,5 \%$ \\
\hline & Kalimantan & 18 & $9 \%$ \\
\hline & Sulawesi & 14 & $7 \%$ \\
\hline & Papua \& Maluku & 7 & $3,5 \%$ \\
\hline & Bali \& Nusa Tenggara & 72 & $36 \%$ \\
\hline \multirow[t]{8}{*}{ Choice of online shop } & Bukalapak & 20 & $10 \%$ \\
\hline & Tokopedia & 54 & $27 \%$ \\
\hline & Shoope & 96 & $48 \%$ \\
\hline & Lazada & 21 & $10,5 \%$ \\
\hline & Blibli & 6 & $3 \%$ \\
\hline & Zalora & 1 & $0,5 \%$ \\
\hline & Adidas & 1 & $0,5 \%$ \\
\hline & Others & 1 & $0,5 \%$ \\
\hline
\end{tabular}

Source: Primary data processed. 
To know the validity of each indicator by looking at the value of loading factor of each variable being researched. Hair et al. (2010), the validity test can be fulfilled when the value of loading factor is above 0.5. In table 2 It appears that the value of all the loading factor > 0.5 So deduced all indicators are declared valid.

Reliability tests are related to the measurements proven by testing consistency and stability. The reliability test is interpreted as a level where measurements are used free of random errors and have consistent results. The reliability test in this study can be seen based on the value of cronbach's alpha and composite reliability. Cronbach's alpha is a measure of reliability that has values ranging from zero to one (Hair et al., 2010). The minimum construction reliability is 0.7 (Hair et al., 2010). In table 2 It appears that the value of reliability test result of each variable either cronbach's alpha or composite reliability is worth $>0.7$ so that it can be concluded that the measurement results of all latent variables are considered reliable.

Table 2 - Test Results

\begin{tabular}{|c|c|c|c|c|}
\hline Item & Variable and Indicator & $\begin{array}{l}\text { Loading } \\
\text { Factor }\end{array}$ & $\begin{array}{l}\text { Cronbach's } \\
\text { Alpha }\end{array}$ & $\begin{array}{l}\text { Composite } \\
\text { Reliability }\end{array}$ \\
\hline & Flash Sale (X1) & & 0,887 & 0,912 \\
\hline $\mathrm{X} 1.1$ & $\begin{array}{l}\text { Display website flash sale online (such as bukalapak, tokopedia, } \\
\text { shopee, lazada etc.) is very easy to use }\end{array}$ & 0,796 & & \\
\hline $\mathrm{X} 1.2$ & Shopping flash sale online is easy & 0,893 & & \\
\hline $\mathrm{X} 1.3$ & discount prices offered flash sale online is very interesting & 0,762 & & \\
\hline $\mathrm{X} 1.4$ & The products sold in the online type flash sale range & 0,650 & & \\
\hline X1.5 & Online sales time for flash sale products is limited & 0,808 & & \\
\hline X1.6 & $\begin{array}{l}\text { When the flash sale online store program limits the number of } \\
\text { products offered }\end{array}$ & 0,813 & & \\
\hline $\mathrm{X} 1.7$ & I feel safe shopping flash sale online & 0,664 & & \\
\hline & Product Knowledge (X2) & & 0,825 & 0,870 \\
\hline X2.1 & $\begin{array}{l}\text { I know the detailed information of the product specifications sold } \\
\text { in flash sale }\end{array}$ & 0,688 & & \\
\hline $\mathrm{X} 2.2$ & $\begin{array}{l}\text { I know an overview of the quality of flash sale products from } \\
\text { information in online stores }\end{array}$ & 0,767 & & \\
\hline $\mathrm{X} 2.3$ & I know the benefits of products sold in flash sale in online stores & 0,579 & & \\
\hline X2.4 & I know the product information of flash sale with a brand $\mathrm{i}$ know & 0,678 & & \\
\hline X2.5 & I remember the product flash sale which benefits i have ever felt & 0,865 & & \\
\hline X2.6 & $\begin{array}{l}\text { I know the quality of flash sale products based on experience } \\
\text { using }\end{array}$ & 0,767 & & \\
\hline & In Home Shopping Tendency (X3) & & 0,813 & 0,862 \\
\hline X3.1 & I can make a purchase of flash sale online from anywhere & 0,595 & & \\
\hline X3.2 & $\begin{array}{l}\text { I love buying products sold in flash sale online without having to } \\
\text { leave home }\end{array}$ & 0,809 & & \\
\hline X3.3 & I made a purchase of flash sale products online from home & 0,635 & & \\
\hline X3.4 & I completed all the online product purchasing process from home & 0,712 & & \\
\hline X3.5 & I use a computer, smartphone or other device in online shopping & 0,745 & & \\
\hline X3.6 & $\begin{array}{l}\text { Computer desktop/Smartphone device makes it easy for me to } \\
\text { shop online }\end{array}$ & 0,776 & & \\
\hline & Purchase Decision $(Y)$ & & 0,821 & 0,872 \\
\hline Y1 & $\begin{array}{l}\text { In the event of flash sale in my online store immediately decided } \\
\text { to buy a quality product }\end{array}$ & 0,696 & & \\
\hline Y2 & $\begin{array}{l}\text { In the event of flash sale in the online store I bought a product } \\
\text { with a brand I know }\end{array}$ & 0,805 & & \\
\hline Y3 & I bought a flash sale product in a trusted online store & 0,576 & & \\
\hline Y4 & I bought a flash sale product with quantity as needed & 0,605 & & \\
\hline Y5 & $\begin{array}{l}\text { When the flash sale lasted for a limited time I immediately bought } \\
\text { the product sold }\end{array}$ & 0,814 & & \\
\hline Y6 & Easy payment makes me buy a product at the time of flash sale & 0,852 & & \\
\hline
\end{tabular}

Source: Primary data processed.

Testing discriminant validity done to ensure each concept of each latent variable differs from other variables. The Model is said to have a good discriminant validity if any AVE square root value indicator of a latent variable has a value greater than the AVE square root value if it is correlated with other latent variables. In table 3 The calculation of FornellLarcker criterion it appears that AVE square root value is greater than the correlation between other latent variables so that the model can be declared has a good discriminant validity. 
Table 3 - AVE Square Root Correlations

\begin{tabular}{lcccc}
\hline \multicolumn{1}{c}{ Variable } & $\begin{array}{c}\text { Flash Sale } \\
(\mathrm{X} 1)\end{array}$ & $\begin{array}{c}\text { Product Knowledge } \\
(\mathrm{X} 2)\end{array}$ & $\begin{array}{c}\text { In Home Shopping } \\
\text { Tendency }(\mathrm{X} 3)\end{array}$ & $\begin{array}{c}\text { Purchase } \\
\text { Decision }(\mathrm{Y})\end{array}$ \\
\hline Flash Sale (X1) & 0,774 & & & \\
Product Knowledge (X2) & 0,217 & 0,729 & & \\
In Home Shopping Tendency (X3) & 0,265 & 0,403 & 0,716 & 0,733 \\
Purchase Decision (Y) & 0,660 & 0,198 & 0,204 & 0 \\
\hline
\end{tabular}

Source: Primary data processed.

\section{RESULTS AND DISCUSSION}

In this research using four main variables namely flash sale, product knowledge, in home shopping tendency and purchase decisions. The items of the statement for the variable are spread by questionnaire or poll to 200 respondents.

To know the influence between variables in the study conducted testing using SmartPLS software, then done test path analysis obtained result as shown in figure 2.

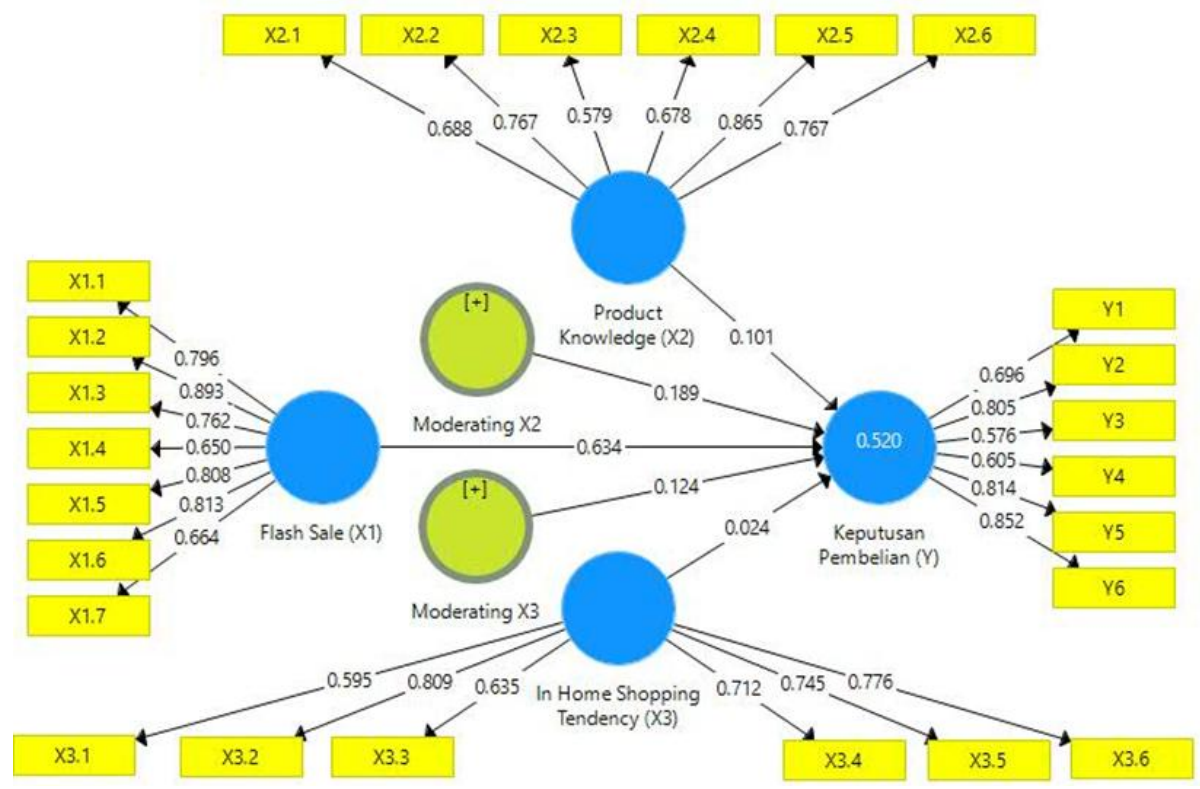

Figure 2 - Path Analysis Diagram

In Figure 2, the R Square obtained 0.520 This value entered moderate category and can be stated that the dependent variable of purchase decision is influenced by the variable flash sale, product knowledge and in home shopping tendency of $52 \%$ while the remainder is $48 \%$ influenced by other variables that do not exist in this study.

Table 4 - Path Analysis Output Results Use SmartPLS

\begin{tabular}{cccccc}
\hline Hypothesis & Path & Original & S Statistics & P Values & Conclusion \\
\hline H-1 & Flash Sale $(\mathrm{X} 1)->$ Purchase Decision $(\mathrm{Y})$ & 0,634 & 12,514 & 0,000 & $\begin{array}{c}\text { Positive and } \\
\text { Significant } \\
\text { H-2 }\end{array}$ \\
Moderating X2 $->$ X1 Purchase Decision $(\mathrm{Y})$ & 0,189 & 2,953 & 0,003 & $\begin{array}{c}\text { Positive and } \\
\text { Significant }\end{array}$ \\
H-3 & Moderating X3 $->$ X1 Purchase Decision $(\mathrm{Y})$ & 0,124 & 2,670 & 0,008 & $\begin{array}{c}\text { Positive and } \\
\text { Significant }\end{array}$ \\
\hline
\end{tabular}

Source: Primary data processed, significant levels $<0,05$.

According to table 4 , it is revealed that the relationship between flash sale and purchase decision has a value of $T$ statistics of $12.514>T$ value of table 1.96. If viewed from the value of $P$ value of $<0.05$ so that the first hypothesis $(\mathrm{H} 1)$ is accepted is the influence of 
flash sale on the purchase decision table 4, indicating the value of T statistics $>1.96$ and the value of the $<0.05 \mathrm{P}$ value in relation to the influence of product knowledge moderation on the effect of flash sale on purchase decisions from this value it can be concluded that the second hypothesis $(\mathrm{H} 2)$ is also declared acceptable that the product knowledge moderate the effect of flash sale toward purchasing decisions. The effect directly from the product knowledge variable to the purchase decision is not significantly seen in the value of $T$ statistics $<1.96$ and the value of $P$ value $>0.05$.

According to table 4, it is known that the direct influence of variables in home shopping tendency toward purchase decisions is also not significant which is seen at the value of $T$ statistics < 1.96 and $P$ value $>0.05$. The effect of moderation from in home shopping tendency to the effect of flash sale toward purchase decision was obtained T statistics value of $2.670>1.96$ and $P$ value of $0.008<0.05$, so it can be concluded that the third hypothesis $(\mathrm{H} 3)$ is also declared acceptable.

Table 5 - Moderation variable influence test results

\begin{tabular}{lcccc}
\hline Path & $\begin{array}{c}\text { Original Sample } \\
(\mathrm{O})\end{array}$ & $\begin{array}{c}\text { T Statistics } \\
(|\mathrm{O} / \mathrm{STDEV}|)\end{array}$ & $\begin{array}{c}\text { P Values } \\
\text { Conclusion }\end{array}$ \\
\hline Product Knowledge (X2) -> Purchase Decision (Y) & 0,101 & 1,585 & 0,114 & Significant \\
Moderating (X2) -> Flash Sale (X1) -> Purchase Decision (Y) & 0,189 & 2,953 & 0,003 & Significant \\
In Home Shopping Tendency (X3) -> Purchase Decision (Y) & 0,024 & 0,454 & 0,650 & Significant \\
Moderating X3 -> Flash Sale (X1) -> Purchase Decision (Y) & 0,124 & 2,670 & 0,008 & Significant \\
\hline
\end{tabular}

Source: Primary data processed, significant levels $<0,05$.

In table 5 shows the influence directly from the product knowledge (X2) variable toward purchase decision $(\mathrm{Y})$ is not significant that is seen in the value of $\mathrm{T}$ statistics $<1.96$ and the value $P$ value $>0.05$ while the moderation effect of the product knowledge (X2) variable toward the flash sale $(\mathrm{X} 1)$ relationship with the purchase decision $(\mathrm{Y})$ is significant, so that the variable moderation of product knowledge interacted with independent variables (flash sale) without being independent variables and concluded that the product knowledge is a pure moderator variable.

Based on table 5 also known influence directly from variables in home shopping tendency toward purchase decisions is also not significant value T statistics $<1.96$ and $\mathrm{P}$ value $>0.05$. While the moderation effect of the variable in home shopping tendency $(X 3)$ toward the flash sale $(\mathrm{X} 1)$ relationship to the purchase decision $(\mathrm{Y})$ is significant. From the explanation it is concluded that the variable moderation in home shopping tendency is a pure moderator variable.

Based on the calculations using smartPLS it is known that the flash sale variable gives a positive and significant influence of 0.634 to the consumer purchase decision in the online store. This influence implies that the better application of sales by flash sale method of comfort, convenience, attraction, time, number of products, product diversity and shopping safety will give positive influence or the higher level of consumers to decide to buy flash sale products sold in online store.

The results of this study are in line with research conducted by Sujata, Menachem, Akshay \& Viraj (2017) in India, where the flash sale strategy of selling products by providing discounted prices will lead to increased sales that are ultimately able to increase the revenue of e-commerce companies. The results of this research also strengthened one of the research results of Kannan, Babu, Hu, \& Narasimhan (2014) where the sales method with flash sale turned out to increase visitors to the main website and can increase the daily sales for all products sold on the site. The research is also in line with Vannisa, Fansuri \& Ambon (2020) his research stated there are positive and significant effects of flash sale on shopping enjoyment and impulse buying where based on one of Seock \& Bailey's Research (2008) stating that shopping enjoyment have a positive influence on information search and online purchases or the more powerful shopping enjoyment the decision to shop or buy products will be increasing. 
Based on the results of testing known the moderation influence of the product knowledge value $T$ statistics $>1.96$ and $P$ value of $<0.05$ where this indicates that the variable of product knowledge moderated the effect of flash sale on the purchase decision significantly with a magnitude of positive influence 0.189 . Positive values mean that the higher consumer knowledge of the product strengthens the effect of flash sale on purchasing decisions or strengthen consumer options in deciding to buy products sold by the flash sale method.

In table 5 It is known that the variable moderation product knowledge is a pure moderator variable by providing positive moderation influence/strengthening the effect of flash sale on purchasing decisions. The findings in line with the research from Pucci, T., Casprini, E., Nosi, C., \& Zanni, L. (2018) expressed the relationship that knowledge provides a moderation effect on the relationship of a variable that affects the purchase decision, in which the study saw the influence of the use of social media against the purchase of online wine products. The findings also support the findings on the influence of product knowledge that is researched by Fenglin, L., \& Shasha, Z. (2014) i.e. consumers with high product knowledge will try to do more search online information related to the products sold and based on research Juniors \& Abbas (2018) The quality of information positively affect customer purchasing decisions through e-commerce.

In table 5, it is revealed that the value of T stastistics is $>1.96$ and the value $P$ value of $<0.05$, it states that the variables in home shopping tendency moderate the influence of flash sale toward purchasing decision significantly with a positive influence value of 0.124 . From the test concluded that the higher the tendency of consumers to make purchases from home through online shopping, the stronger the influence of flash sale on the decision of consumer purchases in the online store, can also be seen in table 5 relationship of moderation variables influence with independent variables and dependent that concluded that the variable in home shopping tendency is a pure moderator in this research.

The influence of in home shopping tendency that strengthens consumers in the decision of the purchase of flash sale supports research results related to in home shopping tendency conducted by Seock \& Bailey (2008), where one of its findings stated that there is a positive and significant influence in home shopping tendency against online information search and online clothing purchases.

\section{CONCLUSION AND SUGGESTIONS}

Based on the results of data processing and discussion can be concluded that the flash sale method of selling positive and significant effect toward purchase decisions means that the better application of sales methods by means of flash sale then the decision of consumers to buy will be higher. The product knowledge variable provides a positive and significant moderation effect on the influence of flash sale toward purchase decisions and can be interpreted that the better the product knowledge from consumers will strengthen the effect of flash sale toward purchasing decisions. In home shopping tendency provides positive and significant moderation effects as well as the effect of flash sale toward purchase decisions which implies that the higher the tendency of consumer shopping from home (in home shopping tendency) will strengthen the influence of flash sale toward purchase decisions.

There is a positive influence on the selling method of flash sale toward consumer purchase decisions. The results of this research added to the research reference on flash sale and in line with the research results of Sujata, Menachem, Akshay \& Viraj (2017) and, Kannan, Babu, Hu, \& Narasimhan (2014) stating that the method of selling flash sale can increase the sales and revenues of e-commerce companies.

Practically, this research contributes to the taking of management policy for interested parties especially the online sellers namely to increase sales of products is advised to make the online store implement a method of selling flash sale, subsequent sellers flash sale online need to provide product information well and complete especially the side benefits of products sold in order to increase consumer knowledge and ultimately strengthen the 
influence of decision to buy. Sellers in the online store also need to improve the ease in terms of shopping processes, payment methods, and convenience, so that consumers will find it easy to do online shopping activities that will ultimately have a positive effect on the decision consumers buy products sold by flash sale method.

The limitation of this research is that the scope of research conducted includes online store widely so that in the future need to do research on the online store as well as certain age range in order to produce a specific managerial effect. In addition, it is necessary to do also the addition of other independent variables that affect the relationship between the flash sale with purchasing decisions and variables that affect directly on the purchase decision so that expected a research receipt will be better.

\section{REFERENCES}

1. Aday, J. B. (2013), "Identifying the Benefits and Risks Associated With Flash Sale Websites and Their Potential Implications for Return Customers", Texas Tech University.

2. Alturas, B. (2004), "In-Home Shopping Through Internet: Consumer Satisfaction and Perceived Risk", makalah disampaikan pada IADIS International Conference, Madrid Spain 6th - 9th October 2004.

3. Armstrong, G., \& Kotler, P. (2003), Dasar-dasar Pemasaran Jilid 1 (Edisi Kesembilan), Jakarta: Penerbit PT.Indeks Gramedia.

4. Armstrong, G., \& Kotler, P. (2012), Dasar-Dasar Pemasaran Jilid I, Terjemahan Alexander Sindoro \& Benyamin Molan, Jakarta: Penerbit Prenhalindo.

5. Balabanis, G. \& Vassileiou, S. (1999), "Some Attitudinal Predictors of Home-Shopping through the Internet", Journal of Marketing Management, 15:5, 361-385, DOI: $10.1362 / 026725799784870315$.

6. CNN (2020) Daftar toko online yang paling menguasai pasar RI selama 2019, Diunduh 6 Juni 2020 dari https://www.cnnindonesia.com

7. Dailysocial (2018) Dibalik strategi penjualan cepat flash sale lazada indonesia yang telah berjalan satu tahun Diunduh 2 Januari 2019 dari https://dailysocial.id.

8. Darden, W. R., \& Reynolds, F. D. (1971), "Shopping Orientations and Shopping Usage Rates", Journal of Marketing Research, 11, 79-85.

9. Deavaj, Fan, \& Kohli. (2003), "E-Loyality Exclusive Ideal or Competitive", Edge Communication of the ACM.46 (9), 184-191.

10. Ercis, A., \& Bilal C. (2018), "Impact of Value Perceptions on Luxury Purchase Intentions: Moderating Role of Consumer Knowledge", 4th Global Business Research Congress (GBRC - 2018), Vol.7-p.52-56.

11. Fenglin, L., \& Shasha, Z. (2013), "The moderating effect of product knowledge and product involvement on online information search behavior", makalah disampaikan pada The Twelfth Wuhan International Conference on E-Business, Proceedings 62.

12. Ghozali, I. (2008), Structural Equation Modelling, Edisi II, Semarang: Universitas Diponegoro.

13. Hair, J. F., Black, W. C., Babin B. J., \& Anderson R. E. (2010), Multivariate Data Analysis A Global Perspective. Seventh Edition, Pearson.

14. Hawes, J.M. \& Lumpkin, J.R. (1984), "Understanding the shopper", Journal of the Academy of Marketing Science, 12(4), 200-218.

15. Kannan, N., Babu, K., Hu, Y. J., \& Narasimhan, S. (2016), "Social Media, Flash Sales, and the Maker Movement: An Empirical Analysis", (July 25, 2016). Available at SSRN: https://ssrn.com/abstract=2829855 or http://dx.doi.org/10.2139/ssrn.2829855

16. Kotler, P. (2002), Manajemen Pemasaran, Jilid 1 Edisi Milenium, Jakarta: PT. Indeks

17. Kotler, P., \& Keller, K. L. (2007), Manajemen Pemasaran, Edisi 12, Jilid 1 \& 2, Jakarta: Terjemahan PT. Indeks Kelompok Gramedia

18. Kotler, P.(2008), Manajemen Pemasaran. Dasar-Dasar Pemasaran Edisi 9 Jilid I, Jakarta: PT. Indeks 
19. Kusuma, D. F., \& Septarini, B. G. (2013), "Pengaruh Orientasi Belanja Terhadap Intensi Pembelian Produk Pakaian Secara Online Pada Pengguna Online Shop", Jurnal Psikologi Industri dan Organisasi Vol 02.

20. Lin, L. Y., \& Chen, C. S., (2006), "The influence of the country-of - origin image, product knowledge and product involvement on consumer purchase decisions: an empirical study of insuranceand catering services in Taiwan", Journal of Consumer Marketing Vol.23 No.5, 248-265.

21. Maarif, N. (2020), Shopee Jadi e-Commerce Terpopuler di Indonesia, diunduh 20 Maret 2020 dari https://inet.detik.com

22. Mahmoud, T.O., Ibrahim, S. B., \& Hasaballah, A. H. A. (2017), "Does Environmental Knowledge moderate The Relationship Between Green Marketing Mix and Purchase Intention", makalah disampaikan pada Conference: 8th Global Islamic Marketing Conference, At Turkey.

23. Peter, J. P., \& Olson, J. C. (2010), Consumer behavior and Marketing Strategy 9th ed, New York. USA: Mc. Graw Hill.

24. Pucci, T., Casprini, E., Nosi, C., \& Zanni, L. (2018), "Does social media usage affect online purchasing intention for wine? The moderating role of subjective and objective knowledge", British Food Journal, Emerald Publishing Limited 0007-070X.

25. Ramadhan, B. (2020), Data Internet di Indonesia dan Perilakunya Tahun 2020, Diunduh 6 Juni 2020 dari https://teknoia.com.

26. Sahavashishta, D., \& Chadichal, S. S. (2012), "Gone In 60 Seconds-online Flash Sales: The Next Innovation In Indian E-commerce Or Just A Flash In A Pan?-a Critical And Empirical Analysis With Consumer Perspective", Indian Journal Of Management Science (IJMS), Vol II: 24-32.

27. Sam, M. F. M., \& Tahir, M. N. H. (2009). "Website Quality And Consumer Online Purchase Intention Of Air Ticket", International Journal of Basic \& Applied Sciences, 9 (10), 20-25.

28. Schiffman, L. \& Leslie L. K. (2008), Perilaku Konsumen. Edisi Ketujuh. Cetakan Keempat, Jakarta: PT. Indeks.

29. Seock, Y. K., \& Bailey, L. R. (2008), "The Influence of College Students' Shopping Orientation and Gender Difference on Online Information Searches and Purchase Behavior", Internation Journal of Consumer Studies, 32, 113-121.

30. Sodero, A. C., \& Elliot R.(2017) "Demand and Revenue Management of Deteriorating Inventory on the Internet: An Empirical Study of Flash Sales Markets", Journal of Business Logistics Volume 38 Issue 3 , https://doi.org/10.1111/jbl.12157

31. Sujata, J., Menachem D., Akshay, P., \& Viraj, T. (2017), "Impact of Flash Sales on Consumers \& E-Commerce Industry in India", Conference Paper publication at: https://www.researchgate.net/.

32. Swastha, B. \& Irawan. (2008), Menejemen Pemasaran Modern. Cetakan Ketujuh. Yogyakarta: Penerbit LIBERTY.

33. Vannisa D., Fansuri A. \& Ambon I. M. (2020). "The Effect of Flash Sale Program on Shopping Enjoyment and Impulse Buying on Flash Sale on C2C E-Commerce", International Journal of Scientific \& Technology Research Volume 9, Issue 04.

34. Vijayasarathy, L.R., \& Jones, J. M. (2000), "Intentions to shop using Internet catalogues: Exploring the effect of the product types, shopping orientations, and attitudes toward computers", Journal Electronic Market, 10(1), 29-38.

35. Kemp, S. (2020), Digital 2020:3,8 Billion People Use Social Media, diunduh 30 Mei 2020 dari https://wearesocial.com

36. Yuniarty \& Abbas, B. S. (2018), "Faktor-Faktor Penentu Keputusan Pembelian Melalui ECommerce pada PT. GRE", Jurnal Manajemen Indonesia, 18(2), 144-153.

37. Zhang, M., Zhang, J., Cheng, T.C.E., \& Hua, G., (2018), "Why and how do branders sell new products on flash sale platforms?", European Journal of Operational Research, Elsevier, vol. 270(1), pages 337-351. 